\author{
ADAM KWIECIŃSKI \\ ORCID: 0000-0002-2652-2689 \\ Uniwersytet Wrocławski \\ Katedra Prawa Karnego Wykonawczego
}

\title{
PRZEGLĄD ORZECZNICTWA EUROPEJSKIEGO TRYBUNAŁU PRAW CZŁOWIEKA W SPRAWACH POLSKICH Z ZAKRESU PRAWA KARNEGO WYKONAWCZEGO
}

\begin{abstract}
Abstrakt: Niniejsze opracowanie poświęcone jest prezentacji wyroków Europejskiego Trybunału Praw Człowieka w sprawach polskich z przestrzeni prawa karnego wykonawczego. Sprawy tego rodzaju należą bowiem do najczęściej kierowanych do organów strasburskich. Stan taki ma miejsce w zasadzie od początku, odkąd nasz kraj poddał się jurysdykcji Trybunału. Orzeczenia Trybunału w tym zakresie służą nie tylko rozstrzygnięciu konkretnej sprawy, lecz wyznaczają standard postępowania z osobami, wobec których wykonywane są orzeczenia w sprawach karnych, najczęściej skutkujących pozbawieniem wolności.
\end{abstract}

Słowa kluczowe: skazany, kara pozbawienia wolności, prawo karne wykonawcze, prawa człowieka, Europejski Trybunał Praw Człowieka

Europejski Trybunał Praw Człowieka powołano do życia w 1959 roku, a od 1998 roku stał się wyłącznym organem sądowym Europejskiej konwencji praw człowieka (dalej: Konwencja). Trybunał rozpatruje skargi założone przez obywateli 47 państw Rady Europy, które ratyfikowały przedmiotową Konwencję i orzeka w sprawach ewentualnego naruszenia praw człowieka przez państwo-stronę. Jego orzeczenia oparte są na katalogu podstawowych praw i wolności wpisanym w pierwotny tekst Konwencji, który został następnie uzupełniony i rozszerzony w kolejnych protokołach dodatkowych dołączanych stopniowo do tego dokumentu. Rozpatrując zarzuty stawiane państwu-stronie przez pokrzywdzonego, Trybunał nie tylko rozstrzyga konkretną sprawę, ale jednocześnie tworzy wspólne dla społeczności międzynarodowej standardy w dziedzinie praw człowieka, które państwa będące sygnatariuszami Konwencji zobowiązane są zapewnić swoim obywatelom.

Wraz z uznaniem jurysdykcji organów strasburskich przez nasz kraj w dniu 1 maja 1993 roku Trybunał rozpoczął przyjmowanie skarg kierowanych do niego 
przez polskich obywateli. Liczba spraw kierowanych do Trybunału przez naszych rodaków od początku utrzymuje się na wysokim poziomie - w 2018 roku skargi zawisłe przed tym organem stanowiły $2,3 \%$ ogólnej liczby spraw, co sytuuje nasz kraj na 10. miejscu pod względem ich liczby na ogólną pulę 47 państw-stron Konwencji. Celem niniejszego opracowania jest przybliżenie judykatów Europejskiego Trybunału Praw Człowieka zapadłych w sprawach przeciwko Polsce. Kluczem selekcji dla tych spraw, zgodnie z tytułem opracowania, był ich związek z postępowaniem karnym wykonawczym.

W sprawie M.C. przeciwko Polsce ${ }^{1}$ Trybunał zajął się pobiciem w zakładzie karnym, którego ofiarą padł skazany za przestępstwo molestowania seksualnego małoletniego. Skarżący podnosił, że sprawców tego napadu pociągnięto jedynie do odpowiedzialności dyscyplinarnej na gruncie przepisów kodeksu karnego wykonawczego, postępowanie karne zaś - zarówno wobec nich, jak i funkcjonariuszy Służby Więziennej zobowiązanych do zapewnienia bezpieczeństwa w jednostce penitencjarnej - umorzono. Skarżący kwestionował też wysokość zadośćuczynienia uzyskanego $\mathrm{w}$ związku z tym wydarzeniem na drodze cywilnej. Trybunał rozpoznał sprawę pod kątem naruszenia art. 3 Konwencji, zarówno w aspekcie materialnym, jak i proceduralnym. Stwierdzono, iż państwo polskie nie wywiązało się z obowiązku ochrony skarżącego przed nieludzkim, poniżającym traktowaniem. Uznano, że skazany znajdował się w grupie szczególnie narażonej na agresję współosadzonych, co wymagało podjęcia działań w celu ochrony jego bezpieczeństwa. Przyznano jednocześnie, iż zasądzona przez sąd krajowy kwota zadośćuczynienia odbiegała od tej, którą mógłby przyznać Trybunał. Zakwestionowano również sposób, w jaki prowadzone było śledztwo (nie przesłuchano współwięźniów, nie uzyskano zapisów monitoringu, nie ustalono wpływu bezczynności funkcjonariuszy na przebieg zdarzenia).

Zupełnie inny rodzaj zaniedbań administracji penitencjarnej stał się przedmiotem skargi Musiał przeciwko Polsce ${ }^{2}$. Skarżący już w momencie osadzenia $\mathrm{w}$ jednostce penitencjarnej miał bowiem poważne problemy ze zdrowiem psychicznym i dodatkowo chorował na epilepsję. Zarzucał, iż administracja więzienna nie zapewniła mu odpowiedniej opieki medycznej. Trybunał podzielił jego zdanie, dodając, że warunki osadzenia skarżącego nie mogły być uznane za odpowiednie dla zdrowej osoby, a więc tym bardziej nie można ich było uznać za dopuszczalne dla cierpiącego na schizofrenię. Wskazywano nie tylko na nieumieszczenie go w odpowiedniej więziennej placówce leczniczej (szpitalu psychiatrycznym), lecz także na dotykające wówczas polskie więziennictwo strukturalne przeludnienie oraz nieodpowiednie warunki socjalne i bytowe. Trybunał uznał, iż postępowanie, któremu został poddany skarżący w trakcie odbywania kary (w tym leczenie),

1 Wyrok ETPCz z dnia 3 marca 2015 roku w sprawie M.C. przeciwko Polsce, skarga nr 23692/09.

2 Wyrok ETPCz z dnia 20 stycznia 2009 roku w sprawie Musiat przeciwko Polsce, skarga nr 28300/06. 
wypełnia znamiona nieludzkiego i poniżającego traktowania ze względu na jego charakter, czas trwania i dotkliwość, co jest w sprzeczności z art. 3 Konwencji. Władzom krajowym zalecono podjąć niezwłocznie zmiany legislacyjne i organizacyjne w celu zapewnienia odpowiednich warunków odbywania kary wszystkim osadzonym, zwłaszcza cierpiącym na dysfunkcje zdrowotne. W odniesieniu zaś do skarżącego zalecono pilne objęcie go specjalistyczną opieką psychiatryczną i stałym nadzorem lekarskim we właściwej placówce.

Podobny zarzut (niezapewnienia właściwej opieki psychiatrycznej ze strony władz więziennych) sformułowano w sprawie Kudła przeciwko Polsce ${ }^{3}$. Skarżący miał zdiagnozowaną ciężką, przewlekłą depresję, a w trakcie osadzenia odnotowano u niego dwie próby samobójcze. W tym wypadku jednak sędziowie Trybunału nie podzielili opinii skarżącego, uznając, iż standard oraz częstotliwość diagnostyki psychiatrycznej oraz leczenia tego rodzaju zaburzeń dostarczony przez więzienną służbę zdrowia był odpowiedni. W orzeczeniu podkreślono, że obowiązkiem państwa jest zapewnienie takich warunków odbywania kary, aby nie narażały osadzonego na trudności przekraczające nieunikniony poziom cierpienia związany z osadzeniem oraz aby stan zdrowia skazanego był zabezpieczony przez właściwą opiekę medyczną w zakładzie karnym.

Problematyka automutylacji skazanych i odpowiedzialności służb penitencjarnych za tego rodzaju zdarzenia była niejednokrotnie przedmiotem badania Trybunału. W wyroku z 1 czerwca 2010 roku (sprawa Jasińska przeciwko Pol$s c e)^{4}$ sędziowie Trybunału Praw Człowieka zajęli się kwestią ustalenia granic odpowiedzialności administracji więziennej za leczenie psychiatryczne skazanego. W ocenie Trybunału w przedmiotowej sprawie doszło do naruszenia art. 2 Konwencji (prawo do życia), gdyż mimo zauważalnych symptomów pogorszenia się kondycji psychicznej skazanego nie objęto go specjalną procedurą monitorowania osób o wysokim ryzyku aktów samobójczych. Opieka psychiatryczna ograniczyła się jedynie do przepisywania kolejnych leków bez jakiejkolwiek kontroli nad ich gromadzeniem i przyjmowaniem przez chorego. Doprowadziło to w efekcie do zażycia przez niego śmiertelnej dawki i zgonu. Trybunał wskazał, iż wobec osób odbywających karę pozbawienia wolności cierpiących na zaburzenia psychiczne obowiązkiem państwa jest objęcie ich systemem kompleksowej opieki psychiatrycznej, włącznie z diagnostyką, postępowaniem leczniczym i monitoringiem ich zachowań, w tym świadczących o możliwości wystąpienia zamachów na własne życie. W ocenie Trybunału w tamtym okresie miały miejsce systemowe zaniedbania w zakresie gospodarowania farmaceutykami i monitorowania ich przyjmowania przez skazanych w polskim systemie więziennym.

${ }^{3}$ Wyrok ETPCz z dnia 26 października 2000 roku w sprawie Kudta przeciwko Polsce, skarga nr 30210/96.

${ }^{4}$ Wyrok ETPCz z dnia 1 czerwca 2010 roku w sprawie Jasińska przeciwko Polsce, skarga nr 28326/05. 
Na przestrzeni lat poważnym problemem w polskich jednostkach penitencjarnych było powszechne zjawisko strukturalnego przeludnienia. Skutkiem tego skazani nierzadko odbywali karę w warunkach niemieszczących się w pojęciu „humanitarnych". Niedopuszczalny standard socjalno-bytowy miejsc osadzenia był przyczyną licznych skarg. Wiele zarzutów naruszenia w ten sposób art. 3 Konwencji spotykało się z jednostronną deklaracją uznania ich przez przedstawicieli rządu polskiego (sprawa Sochaczewski przeciwko Polsce)5. Jeśli zawarta w niej była jednocześnie propozycja odpowiedniej kwoty zadośćuczynienia dla skarżącego, nierzadko Trybunał rezygnował z rozpoznania takiej sprawy i skreślał ją z listy.

Wśród orzeczeń Europejskiego Trybunału Praw Człowieka odnoszących się do problematyki właściwych warunków bytowych w celi mieszkalnej skazanego zwraca uwagę judykat z 28 marca 2019 roku (sprawa Adamkowski przeciwko Pol$s c e)^{6}$. W wyroku tym Trybunał potwierdził bowiem naruszenie art. 3 Konwencji o ochronie praw człowieka i podstawowych wolności w zakresie zapewnienia odpowiedniej powierzchni życiowej dla skazanego. W tej sprawie interesujący był również zarzut naruszenia art. 6 ust. 1 Konwencji (prawo do sądu). Był on konsekwencją pierwszego wątku, gdyż skarżący wniósł przed sądem krajowym powództwo cywilne o odszkodowanie za osadzenie w warunkach nieodpowiednich. Sąd nie przyznał skarżącemu wnioskowanej przez niego pomocy prawnej z urzędu, a powództwo zostało następnie oddalone. Pouczenie o możliwości wniesienia apelacji nie zawierało jednak zapisu o konieczności złożenia środka odwoławczego wraz z odpisem, do czego wezwał skarżącego sąd po wniesieniu apelacji. Skarżący przebywał w zakładzie karnym i nie miał możliwości wykonania kopii swojego pisma, skutkiem czego złożył spisany z pamięci odpis, który sąd uznał za nieidentyczny $z$ oryginałem i na tej podstawie odrzucił apelację. Trybunał w przedmiotowej sprawie zwrócił uwagę na działanie skarżącego bez profesjonalnego pełnomocnika, który nie został mu przyznany przez sąd. Odniósł się także do kwestii odrzucenia apelacji, a tym samym niewyczerpania krajowych środków, uznając, iż przyczyna tego leży po stronie sądów krajowych, co pozwala przyjąć skargę do rozpoznania także w tym fragmencie. Wskazano ponadto na starania skarżącego co do wypełnienia wymogów formalnych narzucanych przez sąd, a jednocześnie na wadliwe pouczenie skarżącego o potrzebie złożenia odpisu apelacji. W tych okolicznościach uznano, iż takie działanie stanowiło nieproporcjonalne ograniczenie prawa do sądu i naruszenie art. 6 ust. 1 Konwencji. Podobny stan faktyczny i rozstrzygnięcie Trybunału można odnaleźć w innych sprawach (na przykład Parol przeciwko Polsce, skarga nr 65379/13).

5 Decyzja ETPCz z dnia 14 marca 2019 roku w sprawie Sochaczewski przeciwko Polsce, skarga $\mathrm{nr}$ 46091/13.

${ }^{6}$ Wyrok ETPCz z dnia 28 marca 2019 roku w sprawie Adamczewski przeciwko Polsce, skarga nr 57814/12. 
Z kolei sprawa Pawełkowicz przeciwko Polsce ${ }^{7}$ dotyczyła prawa skazanego na karę pozbawienia wolności do poszanowania życia prywatnego i rodzinnego. Skarżący zarzucił naruszenie tego prawa przez polską administrację więzienną poprzez nieudzielenie mu przepustki na pierwszą komunię świętą wnuczka. Polski rząd złożył w tej sprawie jednostronną deklarację uznającą naruszenie art. 8 Konwencji oraz zadeklarował rekompensatę tytułem pokrycia skarżącemu wszelkich szkód, kosztów i wydatków. Skarżący zgodził się na warunki zaproponowane w jednostronnej deklaracji rządowej, skutkiem czego Trybunał uznał sprawę za zakończoną ugodą i skreślił ją z listy spraw.

Kwestię naruszenia art. 8 Konwencji w związku z monitoringiem stref wspólnych pryszniców w zakładzie karnym oraz obecnością funkcjonariusza w trakcie badań lekarskich badano w sprawie Krupicz przeciwko Polsce ${ }^{8}$. Trybunał ustalił jednak, iż w trakcie badań przedstawiciel Służby Więziennej przebywał poza gabinetem lekarza. Ponadto ingerencję w prawa skazanego uznano za niezbędną ze względu na potrzebę zabezpieczenia porządku i bezpieczeństwa na terenie jednostki, a także konieczność zapobieżenia $\mathrm{w}$ ten sposób popełnieniu przez osadzonego nowego przestępstwa. Jeśli zaś chodzi o nagrywanie i utrwalanie obrazu z kamer w strefach kąpielowych, to sprawdzono, iż zapis z monitorów był przekazywany w sposób uniemożliwiający ukazanie części intymnych ciała osadzonych, obsługę systemu audiowizualnego przeprowadzały jedynie osoby upoważnione, a zgromadzony materiał zgodnie z procedurami podlegał we właściwym czasie zniszczeniu. Na podstawie wskazanych ustaleń Europejski Trybunał Praw Człowieka uznał skargę za w sposób oczywisty nieuzasadnioną, jeśli chodzi o naruszenie art. 8 Konwencji.

Spora grupa skarg pochodzących od polskich osadzonych dotyczyła zbyt długiego stosowania lub niewłaściwego przypisania skazanych do reżimu związanego z kategorią „N”, czyli do grupy skazanych, których uznaje się za stwarzających poważne zagrożenie społeczne lub zagrożenie dla bezpieczeństwa zakładu karnego. W sprawie Pawlak przeciwko Polsce $e^{9}$ skarżący podnosił, iż długotrwałe stosowanie wobec niego obostrzeń związanych z nadaniem mu tego szczególnego statusu karnowykonawczego (zaostrzona izolacja w specjalnym oddziale, monitorowane cele mieszkalne, ograniczenie kontaktów bezpośrednich z bliskimi, redukcja do minimum wszelkich form aktywności wewnątrz jednostki, zespolone kajdany używane do poruszania się poza celą, kontrole osobiste itd.) stanowiły zgodnie z art. 3 Konwencji poniżające traktowanie lub karanie. Skarżący zarzucił także naruszenie art. 6 ust. 1 i 13 Konwencji w zakresie bezskuteczności odwołań

${ }^{7}$ Decyzja ETPCz z dnia 5 marca 2019 roku w sprawie Pawetkowicz przeciwko Polsce, skarga nr 62105/14.

${ }^{8}$ Decyzja ETPCz z dnia 18 kwietnia 2019 roku w sprawie Krupicz przeciwko Polsce, skarga nr 6068/12.

9 Wyrok ETPCz z dnia 5 października 2017 roku w sprawie Pawlak przeciwko Polsce, skarga nr 41436/11. 
od decyzji komisji penitencjarnych w tej sprawie (statusu „N”). Trybunał przychylił się do zarzutów skargi, uznając, że stosowanie wszystkich przewidzianych prawem restrykcji przez cały okres przynależności do tej specjalnej kategorii skazanych nie było konieczne z uwagi na cel tych regulacji (zapewnienie bezpieczeństwa jednostki penitencjarnej). Środki tego rodzaju w ocenie Trybunału stanowiły dolegliwość, której stopień przekroczył dolegliwość nieodłącznie związaną z karą pozbawienia wolności.

Poza karą pozbawienia wolności Trybunał zajmował się także badaniem naruszeń praw człowieka w trakcie wykonywania innych środków penalnych. W sprawie Nawrot przeciwko Polsce ${ }^{10}$ sędziowie zajęli się nieprawidłowościami związanymi z wykonywaniem internacji psychiatrycznej orzeczonej tytułem środka zabezpieczającego. Wobec skarżącego toczyły się trzy postępowania karne, w których kolejno w latach 2001, 2008 i 2012 zapadały wyroki skazujące go na: karę pozbawienia wolności, internację psychiatryczną i znów karę pozbawienia wolności. Co istotne, w pierwszym postępowaniu nie zaistniały wątpliwości co do poczytalności skarżącego i nie wystąpiono o opinie biegłych. Zrobiono to natomiast $\mathrm{w}$ trakcie drugiego postępowania, kiedy to stwierdzono poważne zaburzenia psychiczne o charakterze urojeniowym wraz ze zmianami centralnego ośrodka nerwowego; sąd zdecydował zatem o zastosowaniu środka zabezpieczającego i skierowaniu skarżącego do zakładu psychiatrycznego. W trzecim postępowaniu również powołano biegłych, jednak zdiagnozowali oni u niego jedynie osobowość dyssocjalną, niepowodującą zniesienia ani ograniczenia poczytalności tempore criminis. Po zapadnięciu ostatniego orzeczenia skarżący podejmował próby samobójcze w szpitalu i przyznał sądowi, iż symulował chorobę psychiczną. Na podstawie art. 5 ust. 1 i 4 Konwencji kwestionował zasadność utrzymywania internacji psychiatrycznej po wydaniu ostatniej opinii biegłych oraz podważał procedurę dalszego stosowania środka zabezpieczającego, która w jego ocenie nie pozwalała mu na jego efektywne przerwanie. Trybunał nie przychylił się do ostatniego zarzutu. Uznał bowiem, iż zasadność kontynuowania detencji była przedmiotem badania w ramach zarówno okresowych opinii biegłych, jak i orzeczeń sądu, które skarżący zaskarżał, a sąd merytorycznie odnosił się do jego zarzutów. Nie pozwala to zdaniem sędziów ETPCz uznać, iż był pozbawiony prawa do sądowej kontroli swojej detencji. W zakresie pierwszego zarzutu Trybunał uznał, iż przyjęcie przez sąd krajowy interpretacji, że należy kontynuować internację psychiatryczną, podczas gdy już wydano wykluczającą stan niepoczytalności opinię biegłych, było wątpliwe. Trybunał wskazał, iż sądy krajowe nie wzięły pod uwagę okoliczności związanych z poprawą stanu zdrowia skarżącego (powodujących spadek ryzyka zachowań niebezpiecznych) oraz zmiany podstaw, które stanowiły oskarżenie (sprawstwo zabójstwa przypisano innej osobie).

10 Wyrok ETPCz z dnia 19 października 2017 roku w sprawie Nawrot przeciwko Polsce, skarga nr 77850/12. 
Z kolei w sprawie Dejnek przeciwko Polsce ${ }^{11}$ Trybunał zajął się kwestią zasadności i granicy dopuszczalnych dolegliwości związanych z kontrolami osobistymi, którym poddawany był skarżący w czasie pobytu w zakładzie karnym. $\mathrm{W}$ trakcie tych kontroli był on rozbierany i poddawany oględzinom intymnych części ciała. Zdaniem skarżącego były one poniżającym, sprzecznym z art. 3 Konwencji, traktowaniem. Podnosił ich niezasadność w kontekście braku wystarczających powodów i podstaw prawnych do podjęcia tak drastycznych i intensywnych czynności kontrolnych wobec niego (kontrole uzasadniano względami porządku i bezpieczeństwa, a wiązano $\mathrm{z}$ aktywnym uczestnictwem skarżącego w podkulturze więziennej oraz podejrzeniami nielegalnego obrotu środkami odurzającymi w jednostce penitencjarnej). Trybunał uznał, iż działalność administracji więziennej nie przekroczyła poziomu dolegliwości opisanej w art. 3 Konwencji. Skargę zbadano jednak także pod kątem naruszenia art. 8 Konwencji i tutaj już dopatrzono się jego naruszenia. Nie dotyczyło ono jednak niezgodności z prawem (kontrole miały oparcie w odpowiednich przepisach kodeksu karnego wykonawczego) ani braku uzasadnionego celu (był nim porządek i bezpieczeństwo jednostki), a jedynie nieproporcjonalności. W ocenie Trybunału niedopuszczalne było bowiem powoływanie się $\mathrm{w}$ trakcie kontroli na okoliczności zaistniałe wiele miesięcy wcześniej, a stosowanie tak upokarzającego środka wymaga dostarczenia przez władze skarżącemu przekonywującego uzasadnienia.

Niedostateczne warunki opieki zdrowotnej oraz nadmierna długość tymczasowego aresztowania stanowily zarzuty skargi Bujak przeciwko Polsce ${ }^{12}$. Trybunał nie stwierdził naruszenia art. 5 ust. 3 Konwencji co do zasadności stosowania środka zapobiegawczego. Natomiast w zakresie braku właściwego zaopatrzenia medycznego i bytowego tymczasowo aresztowanego dopatrzył się naruszenia art. 3 Europejskiej konwencji praw człowieka. Mimo specjalistycznych zaleceń (korzystanie z kul, twardego materaca i wózka inwalidzkiego) skarżący przez cały okres pobytu w jednostce penitencjarnej nie miał ich zapewnionych przez administrację więzienną. W jego ocenie doprowadziło to do pogorszenia jego i tak złego stanu zdrowia i skutkowało koniecznością zabiegu operacyjnego (skarżący został zwolniony z aresztu w celu poddania się operacji na skutek orzeczenia lekarzy, stwierdzającego, iż dalsze stosowanie tego środka zapobiegawczego może zagrażać jego zdrowiu, a nawet życiu). Trybunał przychylił się do jego stanowiska, uznawszy, iż pozbawienie aresztowanego odpowiedniej opieki medycznej skutkowało dodatkowo uzależnieniem go w wykonywaniu czynności życiowych od pomocy współosadzonych i naruszało jego godność, stanowiąc jednocześnie dolegliwość wykraczającą poza poziom akceptowalny dla zastosowanego wobec niego środka.

${ }^{11}$ Wyrok ETPCz z dnia 1 czerwca 2017 roku w sprawie Dejnek przeciwko Polsce, skarga nr 9635/13.

12 Wyrok ETPCz z dnia 21 marca 2017 roku w sprawie Bujak przeciwko Polsce, skarga nr $686 / 12$ 
Wśród kierowanych z naszego kraju do Europejskiego Trybunału Praw Człowieka spraw jedno z zasadniczych miejsc zajmują te, które dotyczą przedmiotu regulacji prawa karnego wykonawczego. Z pewnością najwięcej z nich obejmuje sytuację osób, które na mocy orzeczenia sądu zostały pozbawione wolności. Przy czym to efektywne pozbawienie wolności przybiera różnorodne postaci: kary pozbawienia wolności, tymczasowego aresztowania, internacji psychiatrycznej orzeczonej jako środek zabezpieczający czy też zatrzymania. Skarżący wskazują głównie na niewłaściwe warunki socjalno-bytowe panujące w instytucjach izolacyjnych, brak należytej opieki zdrowotnej, opieszałość organów sądowych czy też nienależyte traktowanie ich przez administrację i personel tych placówek. Orzeczenia Trybunału zapadające po zbadaniu spraw, poza tym, iż stanowią rozstrzygnięcie konkretnej sprawy, wyznaczają standardy legislacyjne dla krajowego ustawodawcy i kształtują praktykę wykonywania orzeczeń w sprawach karnych. $\mathrm{Z}$ tych powodów wkład judykatów Trybunału w polski system prawnokarny, a w szczególności penitencjarny, wydaje się nie do przecenienia.

\title{
A REVIEW OF JURISPRUDENCE OF THE EUROPEAN COURT OF HUMAN RIGHTS IN POLISH CASES INVOLVING EXECUTIVE CRIMINAL LAW
}

\begin{abstract}
Summary
The following study is devoted to the presentation of judgements of the European Court of Human Rights in Polish cases involving executive criminal law. The cases of this type are among the most frequent types of cases referred to the Strasbourg court. This has been so since the beginning, when Poland rendered itself under the Tribunal's jurisdiction. The Tribunal's rulings in this respect not only serve to settle a specific case, but also set a standard for dealing with persons against whom judgements in criminal matters are being executed, most often resulting in deprivation of liberty.
\end{abstract}

Keywords: convict, imprisonment, executive criminal law, human rights, European Court of Human Rights

\section{BIBLIOGRAFIA}

\section{ORZECZNICTWO}

Decyzja ETPCz z dnia 5 marca 2019 roku w sprawie Pawełkowicz przeciwko Polsce, skarga nr $62105 / 14$.

Decyzja ETPCz z dnia 14 marca 2019 roku w sprawie Sochaczewski przeciwko Polsce, skarga nr $46091 / 13$.

Decyzja ETPCz z dnia 18 kwietnia 2019 roku w sprawie Krupicz przeciwko Polsce, skarga nr $6068 / 12$.

Wyrok ETPCz z dnia 26 października 2000 roku w sprawie Kudła przeciwko Polsce, skarga nr $30210 / 96$.

Przegląd Prawa i Administracji CXX, 2020, cz. 1 i 2

(C) for this edition by CNS 
Wyrok ETPCz z dnia 20 stycznia 2009 roku w sprawie Musiat przeciwko Polsce, skarga nr 28300/06. Wyrok ETPCz z dnia 1 czerwca 2010 roku w sprawie Jasińska przeciwko Polsce, skarga nr 28326/05. Wyrok ETPCz z dnia 3 marca 2015 roku w sprawie M.C. przeciwko Polsce, skarga nr 23692/09. Wyrok ETPCz z dnia 21 marca 2017 roku w sprawie Bujak przeciwko Polsce, skarga nr 686/12. Wyrok ETPCz z dnia 1 czerwca 2017 roku w sprawie Dejnek przeciwko Polsce, skarga nr 9635/13. Wyrok ETPCz z dnia 5 października 2017 roku w sprawie Pawlak przeciwko Polsce, skarga nr 41436/11.

Wyrok ETPCz z dnia 19 października 2017 roku w sprawie Nawrot przeciwko Polsce, skarga nr $77850 / 12$.

Wyrok ETPCz z dnia 28 marca 2019 roku w sprawie Adamczewski przeciwko Polsce, skarga nr $57814 / 12$. 